\title{
Acoustic characterisation of micronekton distribution in French Polynesia
}

\author{
Arnaud Bertrand $^{1, *}$, Robert Le Borgne ${ }^{2}$, Erwan Josse $^{1}$ \\ ${ }^{1} I R D, B P$ 70, 29280 Plouzané, France \\ ${ }^{2}$ IRD, Station Marine d'Endoume, Chemin de la Batterie des lions, 13007 Marseille, France
}

\begin{abstract}
Tuna distribution may be directly linked to food availability, the density of which can be assessed by echo-sounding. A study was performed in the French Polynesian EEZ (Economic Exclusive Zone) between 1995 and 1997 with a $38 \mathrm{kHz}$ echo sounder working down to $500 \mathrm{~m}$ depth. With the settings used, acoustic back-scattered energy may be considered as representative of micronektonic fish biomass and provided information on horizontal and vertical micronekton variabilities and the structure of the echograms. Three different zones were defined by multivariate analysis. The classical biomass decreasing gradient from the equator to higher latitudes did not appear. Instead, the maximum micronekton abundance was found between Marquesas Archipelagos and a west-northwest/eastsoutheast oriented line stretching between 11 and $14^{\circ} \mathrm{S}$, i.e. in a weak convergence, favourable to micronekton development due to the concentration of lower trophic levels with no oxygen limitation in the deep layers. Two zones with very different hydrological features, but with comparable micronektonic abundances, surround the richest micronekton zone. To the north, waters are enriched by the equatorial upwelling, but intense organic matter remineralisation limits oxygen availability under the thermocline. To the south, waters are influenced by the great southern gyre and present oligotrophic characteristics less favourable to micronekton development. The present results suggest that prediction of tuna forage distribution should take not only trophic parameters into account, but also environmental ones. They also suggest that echo-sounding data should be used more extensively in the validation of models predicting tuna forage.
\end{abstract}

KEY WORDS: Acoustics - Micronekton - Tuna forage - Abundance estimation - French Polynesia

\section{INTRODUCTION}

The French Polynesian EEZ (Economic Exclusive Zone) is located in important longline fishing grounds, mainly for bigeye (Thunnus obesus), yellowfin (Thunnus albacares) and albacore tuna (Thunnus alalunga) (Fonteneau 1997, see his Fig. 2.7). Since these fish have a high metabolic demand (Kitchell et al. 1978, Olson \& Boggs 1986), their distribution may be governed by food availability (Sund et al. 1981), particularly in oligotrophic areas. Fishes, molluscs and crustaceans (size-class of 1 to $10 \mathrm{~cm}$ ) of the micronekton are the main tuna prey (Blackburn 1968, Sund et al. 1981). Micronekton distribution and composition have

\footnotetext{
•E-mail: arnaud.bertrand@ird.fr
}

been studied in some parts of the Pacific (Blackburn 1968, Young et al. 1996a,b) but remain poorly studied in the central South Pacific; the principal investigation was carried out by Legand et al. (1972) but, unfortunately, micronekton spatial distribution was mainly described in the vertical plane and from pelagic trawls. However, micronekton biomass and composition studies are known to be biased by this type of sampling (Power 1996), particularly for micronektonic fishes, which are difficult to catch with existing techniques (Roger 1994). Other strategies have, therefore, been developed in micronektonic fish studies, and include modelling and echo-sounding. For example, Lehodey et al. (1998) predicted tuna forage with a coupled 3-dimensional dynamical/biogeochemical model. This type of model may be useful in predicting tuna forage on a large scale. However, it assumes that tuna forage 
directly depends on zooplankton abundance. Acoustic surveys, on the other hand, allow a 2-dimensional and continuous approach to the pelagic habitat and are a good tool when studying the distribution of micronekton. For example, Marchal et al. (1993), Roger \& Marchal (1994) and Marchal \& Lebourges (1996) used acoustics to study the behaviour and distribution of Vinciguerria nimbaria, the main tuna prey south of Liberia in the Tropical Atlantic. This method was also used on dolphin prey by Fiedler et al. (1998).

In the present study, acoustics are used to describe the distribution of micronekton in relation to oceanographic features found in the French Polynesian EEZ, which are the great southern anticyclonic gyre in its southern part and the equatorial upwelling in its northern part. The aim of this study is to provide a typology of micronekton distribution as described by acoustic surveys in a quantitative and qualitative way. In order to understand tuna forage occurrence, micronekton distribution will subsequently be matched with present knowledge of the oceanographic features: ocean circulation (Wyrtki \& Kilonsky 1984, Rougerie \& Rancher 1994), amount of nutrients and oxygen distribution (Murray et al. 1995, Pujo-Pay 1995), primary production (Lindley et al. 1995) and zooplankton distribution (White et al. 1995, Le Borgne \& Rodier 1997).

Acoustic surveys have been conducted in French Polynesia within the framework of the ECOTAP pro- gramme (Etude du Comportement des Thonidés par l'Acoustique et la Pêche/Study of Tuna Behaviour using Acoustics and Fishing), a joint project of ORSTOM (now IRD, Institut de recherche pour le développement), IFREMER (Institut Français de Recherche pour l'Exploitation de la MER) and EVAAM (now SRM, Service des Ressources Marines).

\section{MATERIALS AND METHODS}

Sampling and acoustic surveys. Data were collected on board ORSTOM RV 'ALIS' (28 m long) during ECOTAP experiments carried out in the Society, Tuamotu and Marquesas Archipelagos, from October 1995 to August 1997 (Fig. 1).

Both ECOTAP programme objectives and spatiotemporal constraints imposed acoustic sampling design. Experimental longline fishing was carried out each day. Due to the large geographical extension of the studied zone and logistic constraints, fishing sets were distributed continuously along a route in such a way that the largest possible surface could be sampled (Fig. 1). Acoustic data used in this study came either from diurnal rectangular surveys above the longline, or from nocturnal rectangular or straight surveys between each fishing operation (Fig. 1). In order to work on homogeneous samples, dawn and dusk micronek-
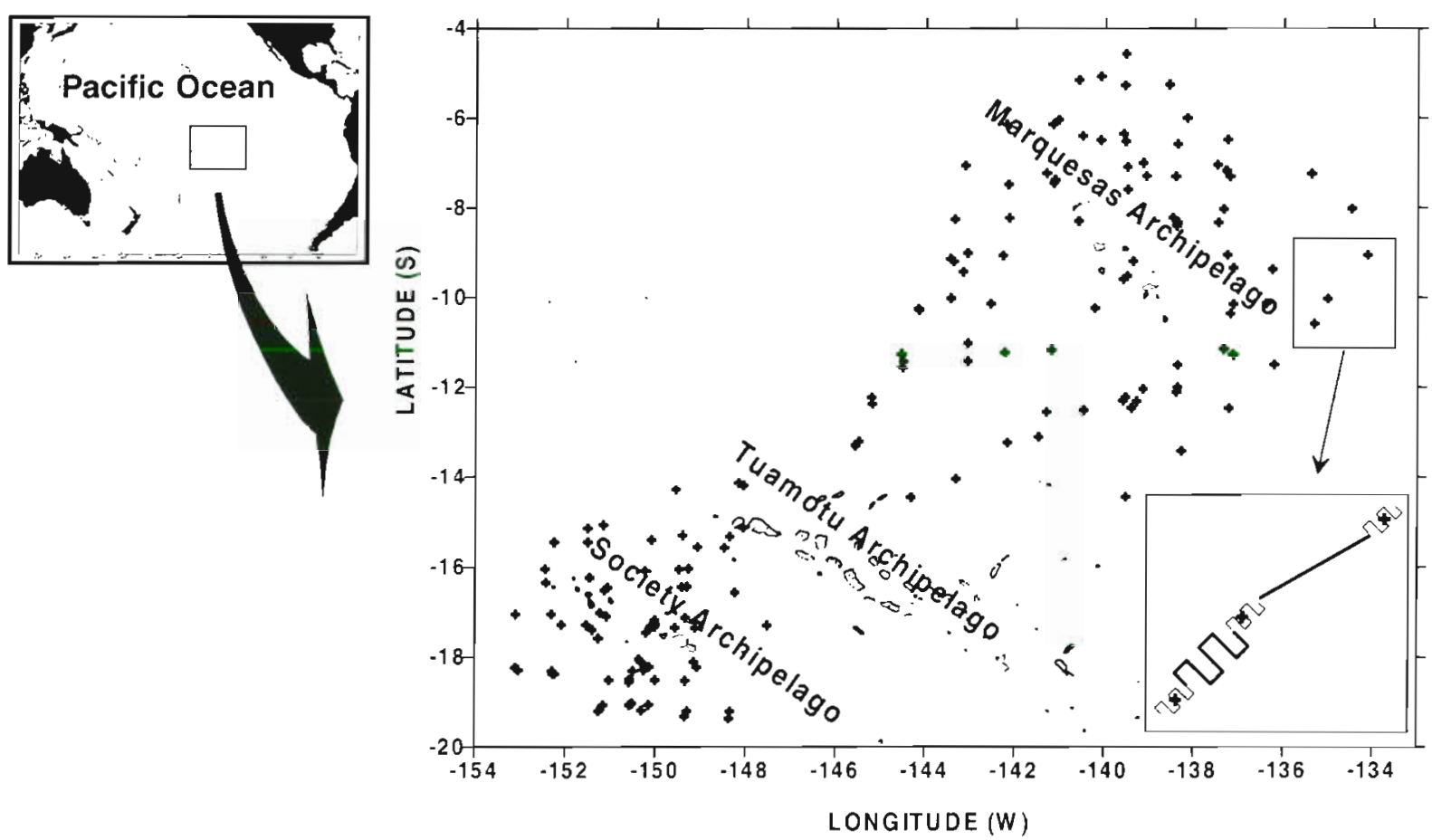

Fig. 1. Longline station positions during ECOTAP cruises in French Polynesia. Lower right: acoustic observations were conducted along rectangular tracks above the longline (fine line) during the daytime and along rectangular or linear tracks between each fishing operation (bold line) at night 
ton migrating periods were avoided. Surveys were considered as nocturnal between 19:30 and 05:50 h, and as diurnal between $07: 30$ and $17: 30 \mathrm{~h}$ local time. A total of 119 nocturnal and 136 diurnal surveys was carried out.

Acoustic data were collected with a SIMRAD EK500 (version 4.01 ) echosounder connected to a $38 \mathrm{kHz}$ split-beam, hull-mounted transducer SIMRAD ES38B (beam angle $6.9^{\circ}$ ) used with a pulse duration of $1 \mathrm{~ms}$. The water column was extended down to $500 \mathrm{~m}$ depth. Acoustic and navigation data were stored via Ethernet on a PC using SIMRAD EP 500 software. On-axis and off-axis calibration was performed with a $60 \mathrm{~mm}$ copper sphere using the standard procedure described in the EK500 operator manual (SIMRAD Subsea 1993). Table 1 gives the main settings used during the ECOTAP cruises.

An integration threshold was applied to acoustic data. The choice of the threshold level involved a compromise so that bias due to noise or integration of nonmicronekton organisms was minimised. On the other hand, too high a threshold could lead to a large micronekton underestimation. The threshold was chosen from theoretical and empirical considerations. A $-65 \mathrm{~dB}$ threshold was first chosen until observations of a tracked tuna, which had a vertical migration linked to a sound scattering layer (SSL) migration (Josse et al. 1998, see their Fig. 7), led to the conclusion that the SSL was detected with a $-70 \mathrm{~dB}$ threshold but not with a $-65 \mathrm{~dB}$ one. Micronekton sampling with a fry pelagic trawl (5 mm mesh) coupled with echo-sounding carried out during ECOTAP cruises led to the conclusion that the fish, and particularly myctophids, were the dominant taxa in the study area (Table 2), a trend which has already been observed in the Pacific Ocean by Young et al. (1996b). With the settings used, a $-70 \mathrm{~dB}$ threshold allowed the observation of a minimal density of 1 myctophid (with a target strength [TS] of $-58 \mathrm{~dB}$ ) in $15.8 \mathrm{~m}^{3}$ Since the swimbladder is supposed to be responsible for 90 to $95 \%$ of the backscattering energy (Foote 1980), other physolclist fish likely have a TS equal to or greater than myctophids because the myctophid swimbladder volume is proportionally lower than that of other physoclists (Kloser et al. 1997, Koslow et al. 1997). It seems that all fish with a swimbladder were likely to be acoustically detected with a -70 dB threshold. Conversely, crustaceans mainly composed of euphausiids (Table 2) are probably not detected since their density must be higher than 100 ind. $\mathrm{m}^{-3}$, a density which is seldom encountered outside of Antarctic waters (Mitson et al. 1996). Finally, due to avoidance, cephalopods were probably undersampled by pelagic trawl, although their target strength has the same range as that of the myctophids (Jefferts et al. 1987. Kajiwara et al. 1990, MacLennan \& Simmonds
Table 1. Main settings of the SIMRAD EK500 echosounder used during ECOTAP cruises

$\begin{array}{lr}\text { Operation menu } & \\ \text { Ping interval } & 0.0 \text { (automatic) } \\ \text { Transmit power } & \text { Normal } \\ \text { Noise margin } & 10 \mathrm{~dB} \\ \text { Tranceiver menu } & \\ \text { Absorption coefficient } & 10 \mathrm{~dB} \mathrm{~km}^{-1} \\ \text { Pulse length } & \text { Medium } \\ \text { Bandwidth } & \text { Auto } \\ \text { Maximum power } & 2000 \mathrm{~W} \\ \text { 2-way beam angle } & -20.9 \mathrm{~dB} \\ \text { Sv transducer gain } & 27.7 \mathrm{~dB} \\ \text { TS transducer gain } & 27.8 \mathrm{~dB} \\ \text { Angle sensitivity } & 21.9 \\ 3 \text { dB beam angle } & 6.9^{\circ} \\ \text { Alongship oftset } & -0.07^{\circ} \\ \text { Athwart ship offset } & 0.21^{\circ}\end{array}$

1992). The stomach content composition of tuna caught by longline during the ECOTAP programme differed from pelagic trawl sample composition (Table 2), owing especially to sampling efficiency problems (Roger 1994, Young et al. 1996b). Since tuna forage is mainly composed of both taxa sampled by pelagic trawl and larger animals foraging on taxa sampled by the pelagic trawl such as myctophids, the acoustic back-scattered energy may be considered representative of micronektonic fish (and probably cephalopod) biomass.

Parameter description. Describers of acoustic profiles, horizontal and vertical micronekton variabilities and morphology of the echograms have been either computed or measured in order to achieve a typology of the study area (Table 3). At each station, cruise number, latitude (computed by 16 classes of $1^{\circ}$ ), longitude and season, i.e. dry from May to October or wet from November to April, were also considered.

Acoustic profiles. For each diurnal or nocturnal survey, a mean acoustic back-scattering energy by surface unit (sa) was calculated on $10 \mathrm{~m}$ thick layers ranging between 10 and $490 \mathrm{~m}$ following a $\log (x+1)$ transformation (Table 3). Total acoustic density, integrated on the whole vertical range (10 to $490 \mathrm{~m}$ ), was also calculated for each survey (Table 3). Back-scattered energy sections and total acoustic densities were used both to compute latitudinal vertical sections and horizontal representations, gridded by kriging with the SURFER software (Golden Software 1995), and to compute multivariate analysis

Horizontal and vertical variability. Vertical variability was determined on each survey by simple describers: mean and variance. The horizontal variability of each survey was quantified using geostatistic methods (Matheron 1965) which are regularly used in fisheries science in order to provide resource spatial pat- 


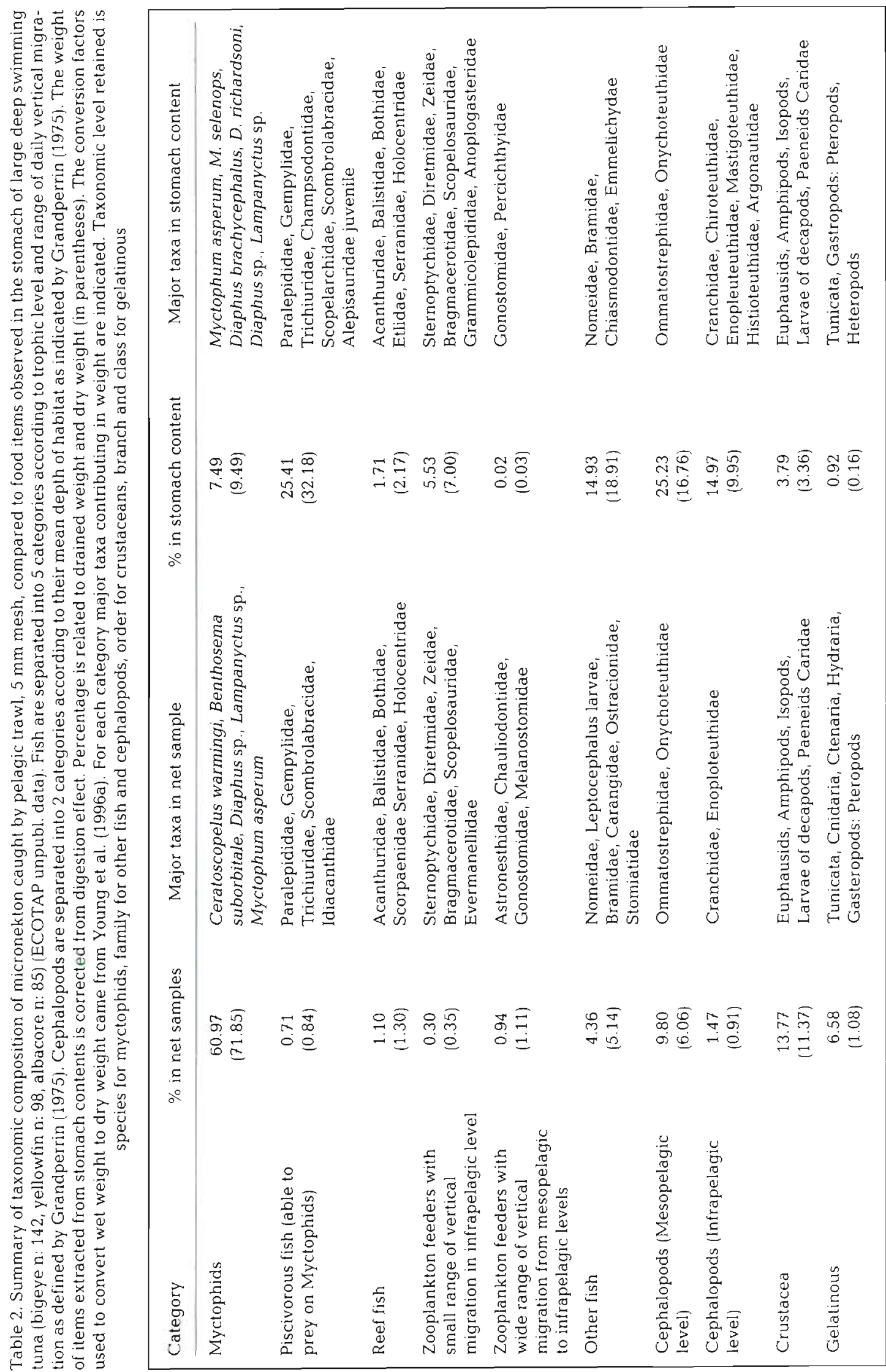


Table 3. Parameters used in multivariate analysis (M: modality, C: continue, A: active, I: illustrative, NU: non-used variables)

\begin{tabular}{|c|c|c|c|c|}
\hline Variable code & Description & Type & Night & Day \\
\hline Cruise & Belonging to one of the 18 ECOTAP cruises & MI & 1 & I \\
\hline Season & Wet (1) or dry (2) season & M & 1 & I \\
\hline Lat & Belonging to one of the 16 classes of latitude & M & 1 & I \\
\hline Long & Longitude & $\mathrm{C}$ & I & I \\
\hline P1 to P49 & Log $(s a+1)$ on a whole prospecting by $10 \mathrm{~m}$ thick layers & $\mathrm{C}$ & I & I \\
\hline Meanv & $\log ($ mean $s a+1)$ by $10 \mathrm{~m}$ thick layers & $\mathrm{C}$ & I & I \\
\hline Varv & Vertical variance & $\mathrm{C}$ & I & I \\
\hline Varh & Geostatistical horizontal variance & $\mathrm{C}$ & I & $\mathrm{NU}$ \\
\hline Range & Geostatistical range & $\mathrm{C}$ & I & NU \\
\hline Total & Log $(s a+1)$ total integrated on the whole water column & $\mathrm{C}$ & I & I \\
\hline $\begin{array}{l}\text { SSL, MSL, TSL, LSL, NSL, LAS, } \\
\text { SSS, SAG, NUL }\end{array}$ & $\begin{array}{l}\text { Presence (2)/absence (1) of the structural descriptors } \\
\text { of the scattering structures during a whole prospecting }\end{array}$ & M & A & A \\
\hline $\begin{array}{l}\mathrm{SSL}_{1-5}, \mathrm{MSL}_{1-5}, \mathrm{TSL}_{1-5}, \mathrm{LSL}_{1-5}, \mathrm{NSL}_{1-5} \\
\mathrm{LAS}_{1-5}, \mathrm{SSS}_{1-5}, \mathrm{SAC}_{1-5}, \mathrm{NUL}_{1-5}\end{array}$ & $\begin{array}{l}\text { Presence (2)/absence }(1) \text { of the structural descriptors } \\
\text { of the scattering structures by } 100 \mathrm{~m} \text { strata from surface } \\
\text { to } 500 \mathrm{~m}\end{array}$ & M & A & A \\
\hline
\end{tabular}

terns (Swartzman et al. 1992, Simard et al. 1993, Pelletier \& Parma 1994, Coyle et al. 1998) and stock assessments (Sullivan 1991, Guillard et al. 1992, Petitgas 1993). Geostatistic methods are particularly recommended in the case of acoustic surveys as acoustic data are generally sampled continuously along transects and are thus spatially correlated. The use of variograms allows variance to be calculated according to spatial autocorrelation and density distribution models.

Geostatistic methods were only applied to nocturnal surveys, as they are more homogeneous than the diurnal ones since most of the biomass is located between the surface and $250 \mathrm{~m}$ at night. The biomass is made of surface non-migrant organisms and of a high proportion of vertically migrating organisms which live in the deep layers during the day. Surface strata nocturnal acoustic density is therefore considered to be a good indicator of the total acoustic density. Thus, the sa values were integrated between 10 and $250 \mathrm{~m}$ with $0.5 \mathrm{~nm}$ ESDU (elementary sampling distance unit).

Nocturnal sampling was designated as rectangular or linear transects (Fig. 1). No anisotropy was observed on any of the rectangular surveys. This was a predictable result as a pelagic habitat is studied at a smaller scale than the large environmental features of spatial anisotropy (Piontkovski \& Williams 1995). Therefore an isotropic model was adjusted on each variogram of the 119 nocturnal surveys using the EVA software (Petitgas \& Prampart 1995), and sill (i.e. geostatistical horizontal variance) and range were measured (Table 3).

Scattering structures coding. Acoustic profiles allow for the study of the quantitative aspect of echograms, therefore the structural information is not taken into account. Thus, acoustic structure morphology is deter- mined by the composition of the specific community and also by physicochemical factors which may be subject to regional changes. For instance, Wiebe (1970) considers that zooplanktonic aggregations are induced by physical processes, and Levin (1992) supposes that, on large scales, patchy krill distribution would be induced by physical processes even though aggregation behaviour may become significant at smaller scales. Finally, Zhou \& Huntley (1996) suppose that behaviour plays a role in zooplankton and micronekton patch dynamics. Therefore, the echo structure represents information which expresses physical and biological phenomena as well. A morphological coding of echograms was undertaken using the method proposed by Petitgas \& Levenez (1996). Nine different types of echogram were defined and were denoted by a 3-letter code. Presence/absence coding is made on an entire nocturnal or diurnal survey and also on $100 \mathrm{~m}$ strata located between the surface and $500 \mathrm{~m}$. For the latter, a number between 1 and 5 was added to the 3 letter code. The different echo types are as follows:

(1) SSL are 'classic' layers, i.e continue on a horizontal plane and are vertically homogenous (Fig. 2a); (2) mountain shaped layers (MSL) are SSL shaped like an inverse ' $V$ ' or a succession of 'mountains' (Fig. 2b); (3) thin scattering layers (TSL) are very thin, dense and stratified SSL (Fig. 2c) (4) loose scattering layers (LSL) are very loose SSL (Fig. 2d); (5) nucleus in scattering layers (NSL) is a dense nucleus inside more homogeneous scattering layers (Fig. 2e); (6) large aggregated structures (LAS) are large, school-shaped structures (Fig. 2f); (7) stick shaped structures (SSS) are aggregated structures with a vertical stick-like aspect (Fig. 2g); (8) small aggregates (SAG) are small aggregated structures (Fig. 2h); (9) absence of echo trace (NUL). 

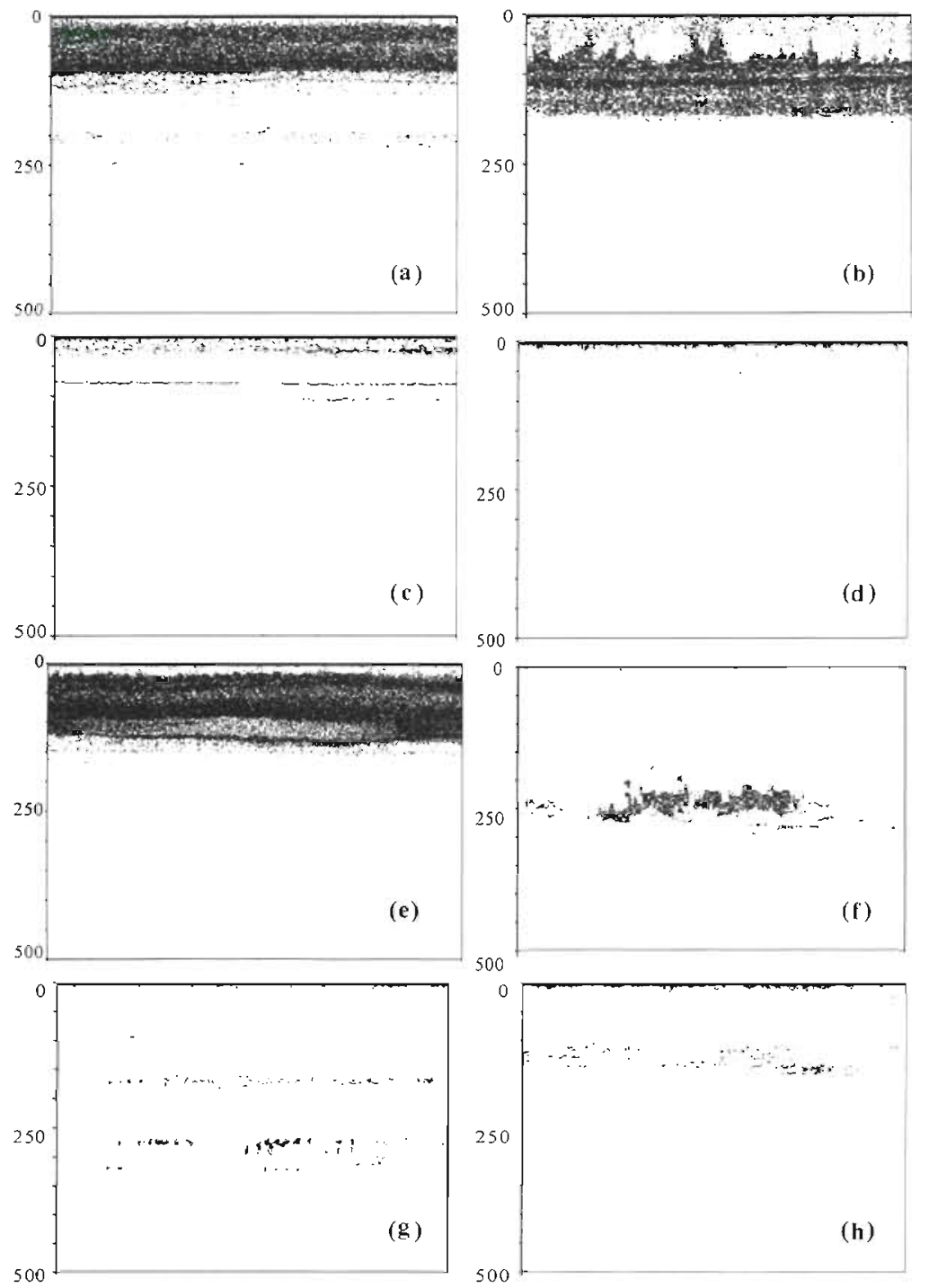

Fig. 2. Echotraces defined for the habitat characterisation. (a) 'Classic' sound scattering layer (SSL), (b) 'mountain' or inverse ' $V$ ' shaped scattering layer (MSL), (c) thin scattering layer (TSL), (d) loose scattering layer (LSL), (e) nucleus in scattering layer (NSL), (f) large aggregated structures (LAS), (g) stick shaped structures (SSS), (h) small aggregates (SAG) factorial correspondence analysis followed by ascending hierarchical clustering analysis, were used considering illustrative variables as active. Results were similar to those of analyses presented here. The SPAD 3.5 software was used for all statistical processing

\section{RESULTS}

Profiles and cartography of backscattering energy by suriace units (sa)

Profiles of sa from all nocturnal samples showed a clear trend, with maximal values lying between 10 and $150 \mathrm{~m}$ (Fig. 3a). Below $150 \mathrm{~m}$, sa suddenly decreased, reaching very low values between 200 and $490 \mathrm{~m}$. Conversely, no diurnal sample sa profiles presented any strong depthlinked trend (Fig. 3b).

Mean latitudinal vertical sections of nocturnal (Fig. 4a) and diurnal (Fig. 4b) sa by depth strata showed that maximum backscattered energy was mainly located between 8 and $13^{\circ} \mathrm{S}$ and that the vertical range was higher in the 8 to $13^{\circ} \mathrm{S}$ zone. The horizontal distribution of nocturnal (Fig. 5a) and diurnal (Fig. 5b) acoustic response confirmed the biomass maximum in this area.

\section{Multivariate analysis results}

Neither seasons nor years were structuring factors in the multivariate analysis so that all nocturnal or diurnal samples were considered simultaneously. Both multi-
Data processing. Multivariate methods are used in order to characterise the micronekton distribution. Multiple factorial correspondence analysis followed by an ascending hierarchical clustering analysis (Saporta 1990) were computed on nocturnal and diurnal samples. Variables used as 'active' in analysis are the structural describers of the scattering structures (Table 3). All other variables are not used in calculation but are projected on factorial plans as 'illustrative' ones. Other multivariate methods, such as principal component analysis and
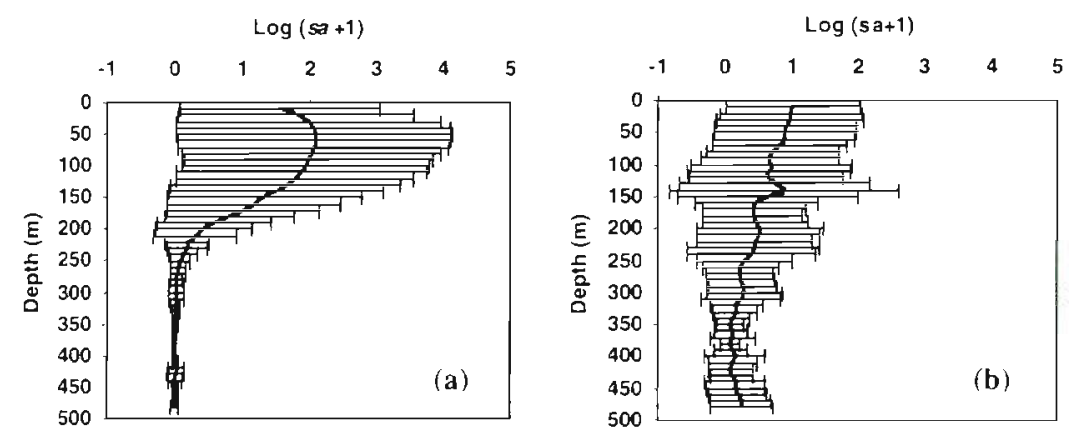

Fig. 3. (a) Nocturnal and (b) diurnal average profiles of acoustic back-scattering by surface (sa) of micronekton with their standard deviation on a logarithmic scale 

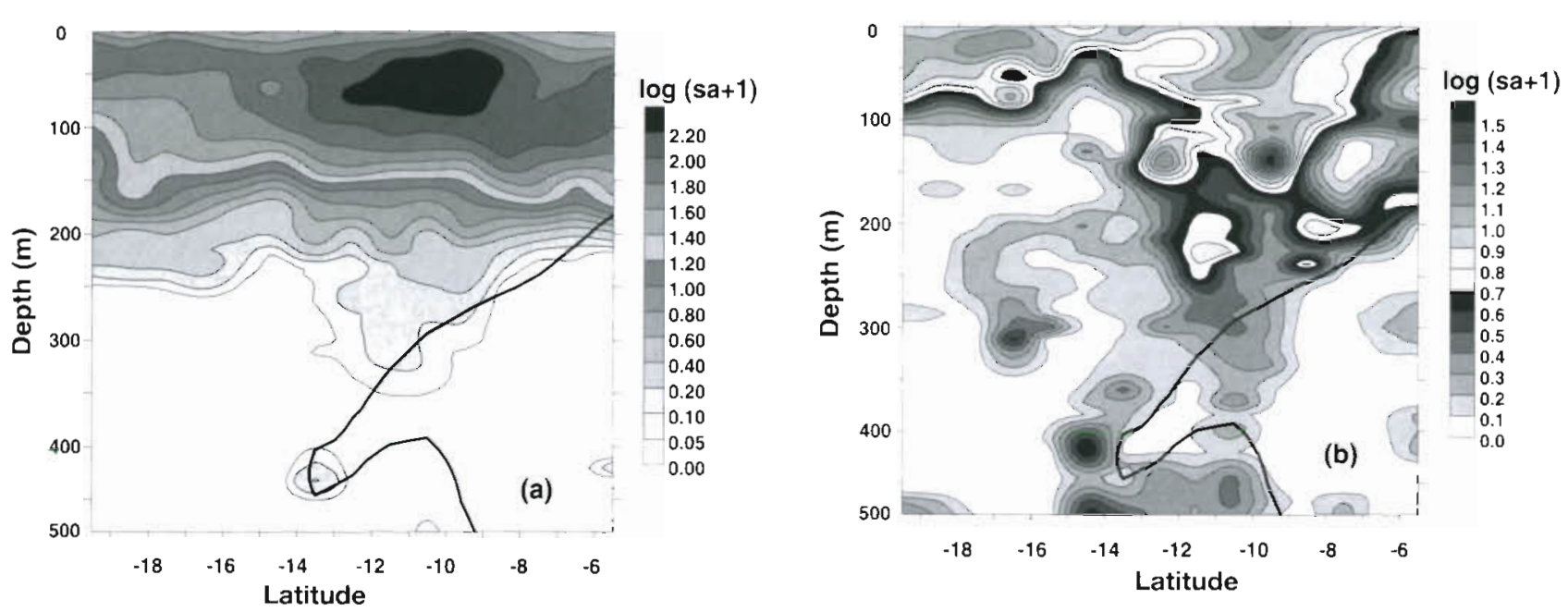

Fig. 4. Latifudinal vertical section of (a) nocturnal and (b) diurnal acoustic back-scattering by surface (sa) of micronekton on a logarithmic scale with the $1.5 \mathrm{ml} \mathrm{l}^{-1}$ oxygen isoline plotted (solid line) on vertical section
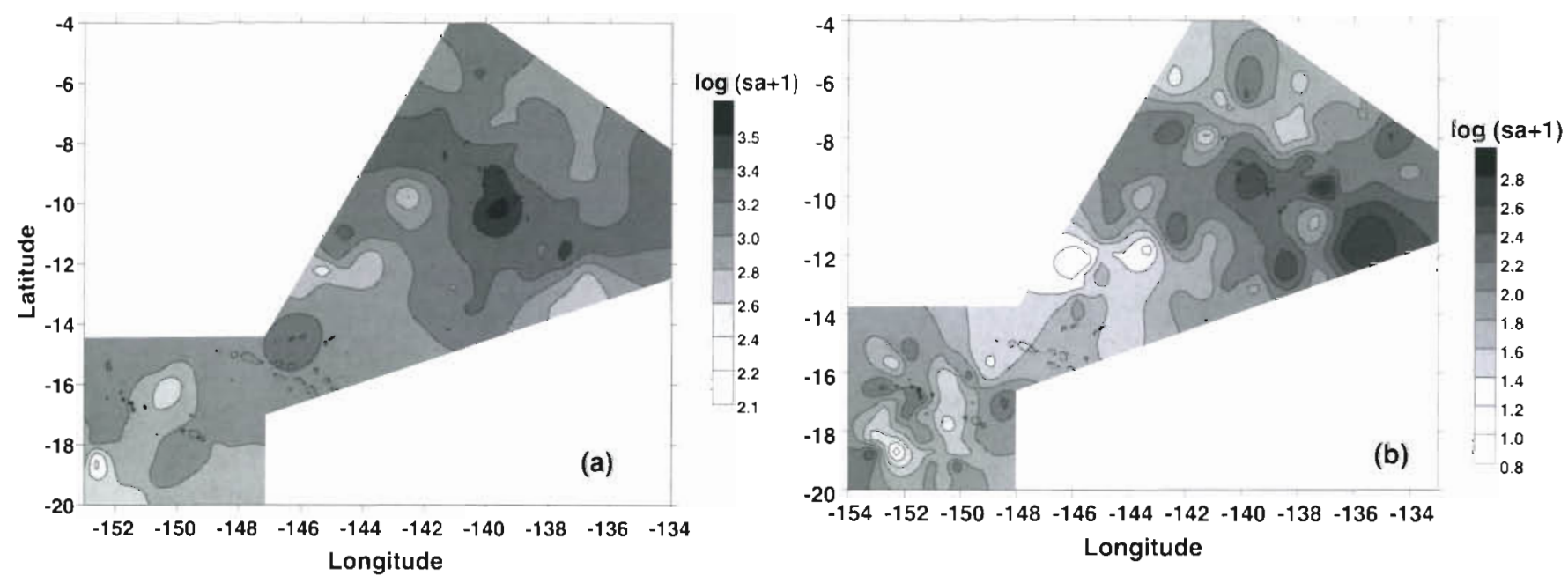

Fig. 5. Spatial distribution of (a) nocturnal and (b) diurnal acoustic back-scattering by surface (sa) of micronekton on a logarithmic scale

variate analyses presented here on nocturnal (Fig. 6) and diurnal (Fig. 7) acoustic samples displayed a similar pattern. In both cases, cluster analysis focused on a 3-class typology which allowed the study area to be divided into 3 zones, following a west-northwest/eastsoutheast oriented line (Fig. 8).

The first zone was located south of a line stretching between 11 and $14^{\circ} \mathrm{S}$ (Fig. 8). It was characterised by a low biomass and a low number of aggregated structures. Maximal detection was located between 10 and $100 \mathrm{~m}$, nocturnal and diurnal SSL was encountered at times between 200 and $300 \mathrm{~m}$, and almost no diurnal SSL was observed between 400 and $500 \mathrm{~m}$. The 'usual' deep migrant layer was located during the day below $500 \mathrm{~m}$ as observed in situ during sporadic integrations of 100 to $600 \mathrm{~m}$ or 0 to $1000 \mathrm{~m}$ layers.
The second zone was located south of Marquesas Archipelago and north of the 11 to $14^{\circ} \mathrm{S}$ line. It was characterised by maximal variance and biomass. At night, SAG occurred below $200 \mathrm{~m}$. Concurrently, NSL were present in the SSL where the biomass maximum was found. During the day, aggregated structures of all kinds (SAG, SSS, LAS) were present on the whole vertical range studied. Relatively high biomasses were encountered between 400 and $500 \mathrm{~m}$ as indicated by deep SSL

The third zone, located north of the Marquesas Archipelago, had many similarities with the first zone although both zones were hydrologically very different. Micronektonic biomass had an average value with respect to the entire study area. Few nocturnal aggregated structures were present. The maximum noctur- 
Factor 2: $15.24 \%$

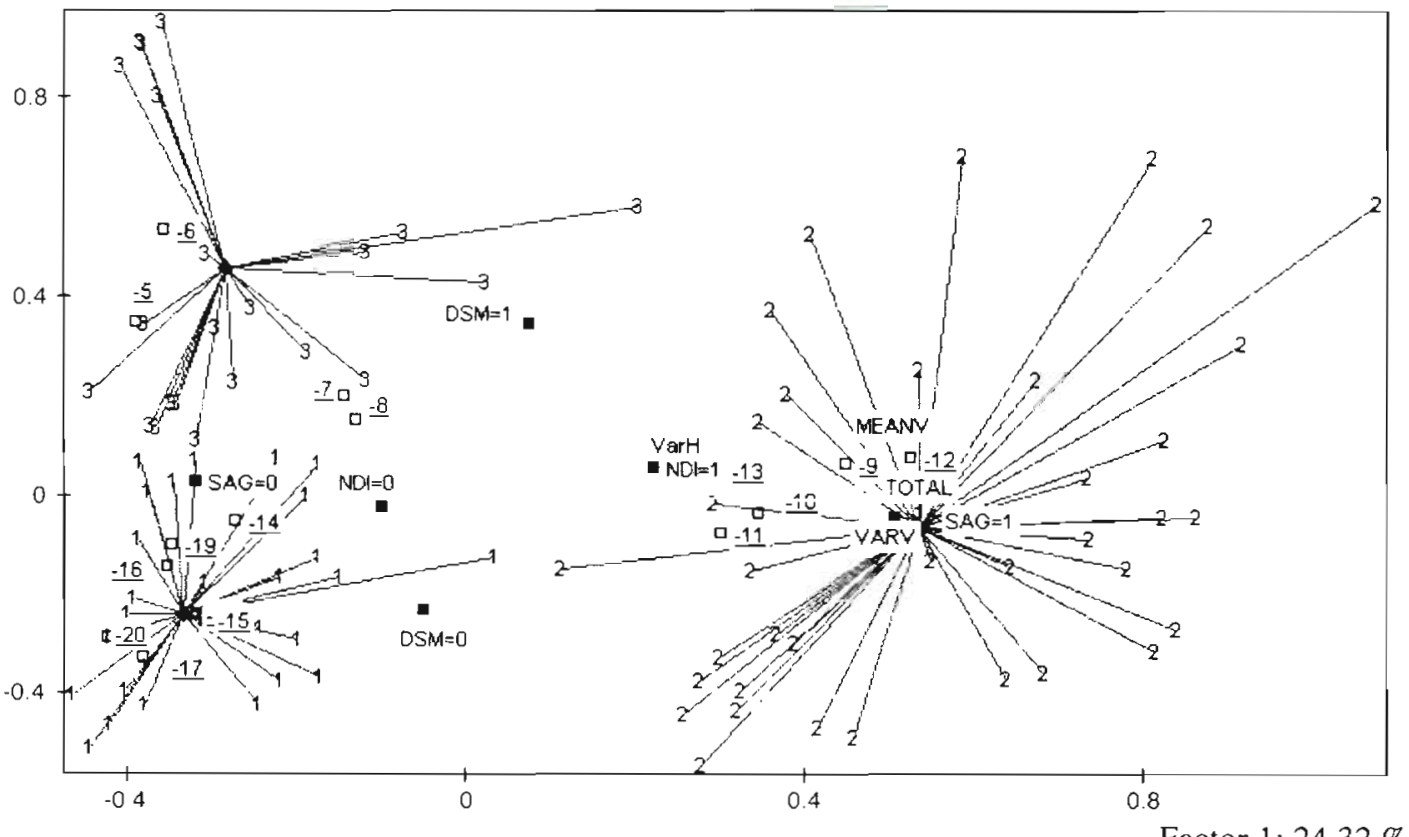

Fig. 6. First 2 axes of the correspondence analysis based on the structural descriptors of the nocturnal scattering structures. Samples are grouped into 3 cluster analysis classes (1 to 3 ). Parameters (0: absence, 1: presence) on the figure are the only ones considered significant and useful

Factor 2: $15.22 \%$

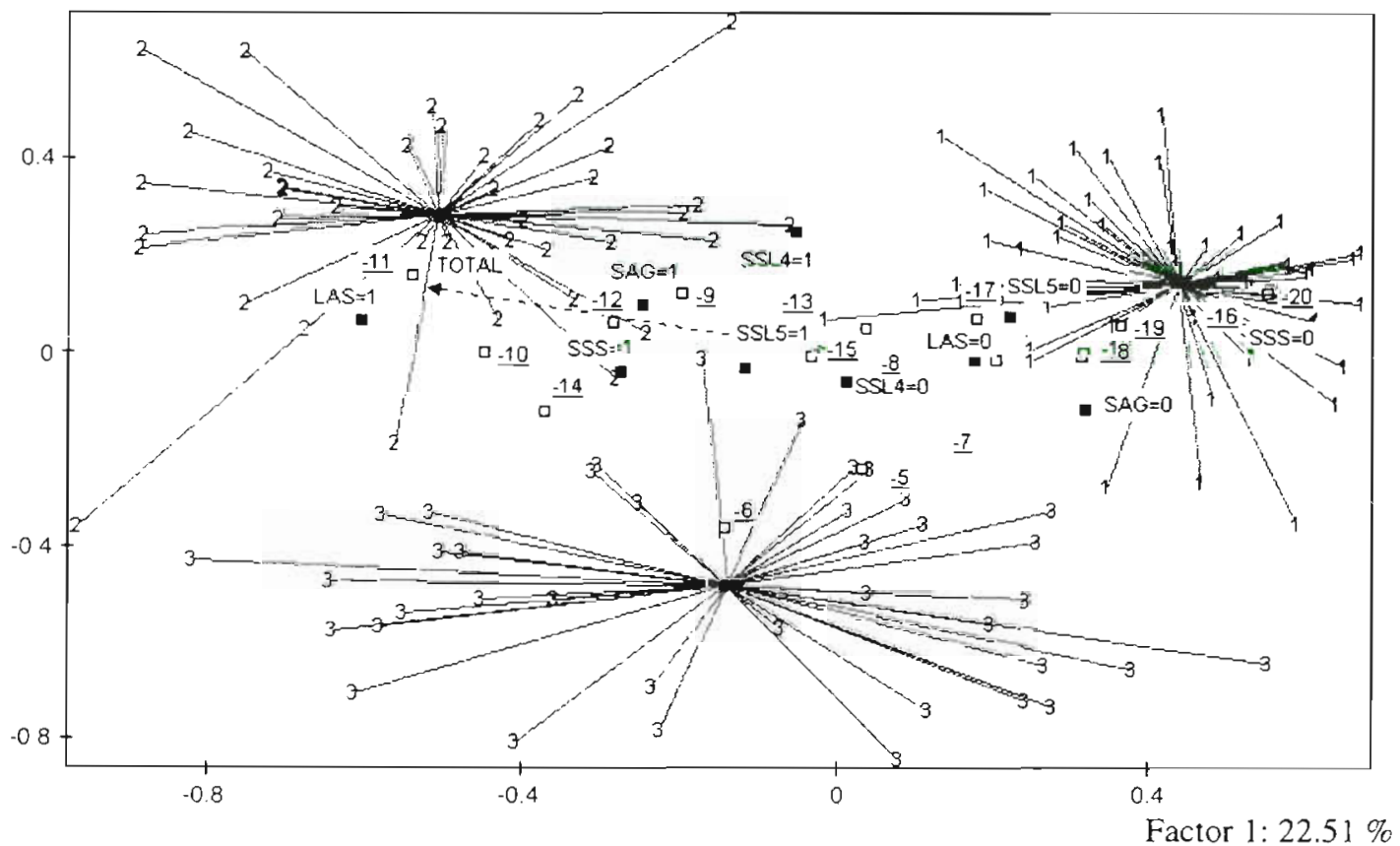

Fig. 7 First 2 axes of the correspondence analysis based on the structural descriptors of the diurnal scattering structures. Samples are grouped into 3 cluster analysis classes ( 1 to 3 ). Parameters ( 0 : absence, 1 . presence) on the figure are the only ones considered significant and useful 


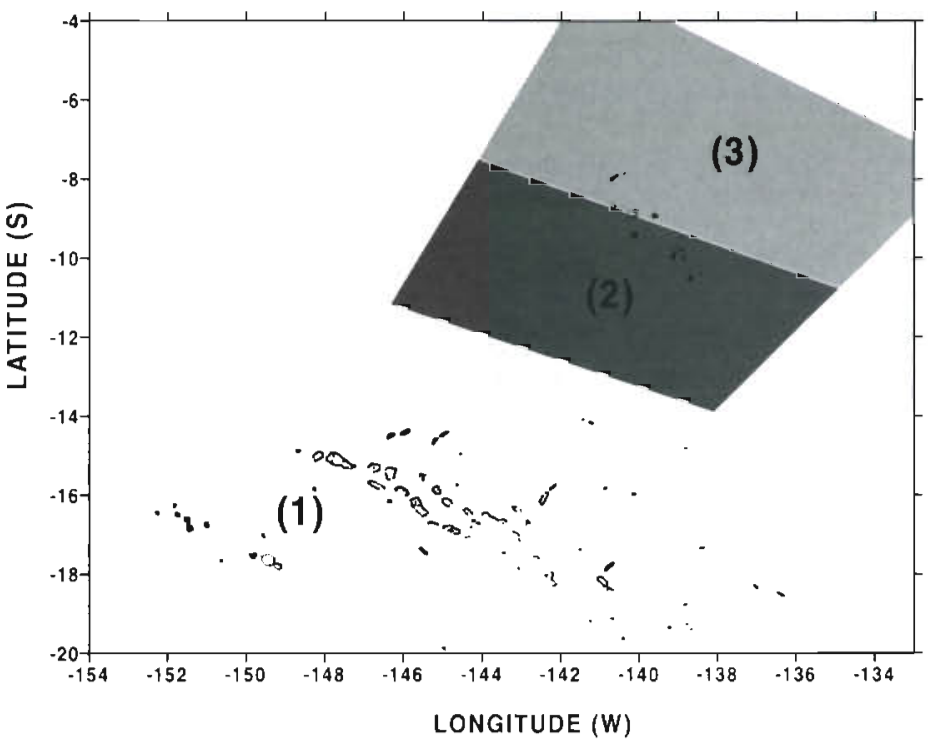

Fig. 8. Micronektonic biomass zones as discriminated by multivariate analysis

nal biomass was located deeper than in the first zone but almost no real SSL were present below $200 \mathrm{~m}$. MSL were often encountered close to the surface. During the day, fewer aggregated structures were found than in the second zone. When they occurred, they were mainly located in the upper $200 \mathrm{~m}$. Detection was much lower below $200 \mathrm{~m}$.

\section{DISCUSSION}

The ECOTAP field programme extended over nearly 2 yr. Therefore, temporal variations could have influenced the results obtained on micronekton density and distribution. However, such an effect was not evidenced by the multivariate analysis, a result which is in agreement with the well known temporal stability of open ocean pelagic ecosystems of the tropical area (Cushing 1959, Walsh 1976, Landry 1981, Le Borgne et al. 1983, Longhurst 1998). It would also indicate that during the study climatic variations had no significant effect on the micronekton of this oceanic province. Thus, the Southern Oscillation Index (SOI), which depicts the climatic situation in the equatorial Pacific, was positive during most of the study (from December 1995 to February 1997) and corresponded to a maximum extension of the high nutrient-low chlorophyll (HNLC) area. The strong El Niño which followed (as indicated by a negative SOI) started at the very end of the study (March 1997) so that the present results might not have been significantly influenced by the climatic change that occurred.
From ECOTAP cruises 3 different characteristic zones may be defined between 4 and $20^{\circ} \mathrm{S}$. Micronekton density is maximal in the central zone stretching mainly from 8 to $13^{\circ} \mathrm{S}$ (Fig. 8). North and south of this zone, its densities are lower but similar, in spite of very distinct physico-chemical environmental conditions which generally prevail. The equatorial upwelling north of the Marquesas is a rich area, and the waters of the South Pacific central gyre south of $13^{\circ} \mathrm{S}$ are oligotrophic (Rougerie \& Rancher 1994). These observations need to be discussed since they appear to be different from general ideas raised in bibliographical data.

Classically, the equatorial upwelling, which is known to be the origin of an increased pelagic productivity, is said to be at the equator or slightly south of it, and biomasses are known to decrease as latitude increases (Vinogradov 1981). This is true for primary productivity which is maximal between $2^{\circ} \mathrm{N}$ and $2^{\circ} \mathrm{S}$ (Lindley et al. 1995, Barber et al. 1996, Chavez et al. 1996, Vinogradov et al. 1997), but not for the mesozooplankton maximum which is shifted several degrees to the south or to the north: between 2 and $5^{\circ} \mathrm{S}$ for Vinogradov (1981) and White et al. (1995) at $140^{\circ} \mathrm{W}$. The reason for this is that the pelagic foodweb evolves whilst the equatorial watermasses are drifting to the southwest. This is due to the meridian component of the South Equatorial Current (SEC) (Vinogradov 1981, Rougerie \& Rancher 1994). Although Vinogradov (1981) and Lehodey et al. (1998) predict a tuna forage biomass maximum at the same latitude as that of the zooplankton, ECOTAP results locate it more to the south (Fig. 8). From what is known of the currents, biogeochemistry and dissolved oxygen distributions, it can be demonstrated that acoustically observed micronekton distribution is realistic.

The equatorial rich zone is generated by the SEC divergence and is limited by 2 convergences: the northern convergence between SEC and NECC (North Equatorial Counter Current) at 4 to $5^{\circ} \mathrm{N}$, and the southern convergence between SEC and SECC (South Equatorial Counter Current), around $8^{\circ} \mathrm{S}$ (Fig. 9). At $140^{\circ} \mathrm{W}, \mathrm{SECC}$ is not always well marked (Rougerie \& Rancher 1994, meridional current profiles of Murray et al. 1995) so that the convergence zone is weak and spread out in latitude. Both equatorial convergences are 'wells' of organic matter which accumulates and is mineralised, and are aggregative systems for micronekton and nekton (Yamamoto \& Nishizame 1986, Power 1996, Kimura et al. 1997, Lehodey et al. 1997). Our measurements of the depth of the photic layer illustrates this (Fig. 10): it is minimal between 8 and 


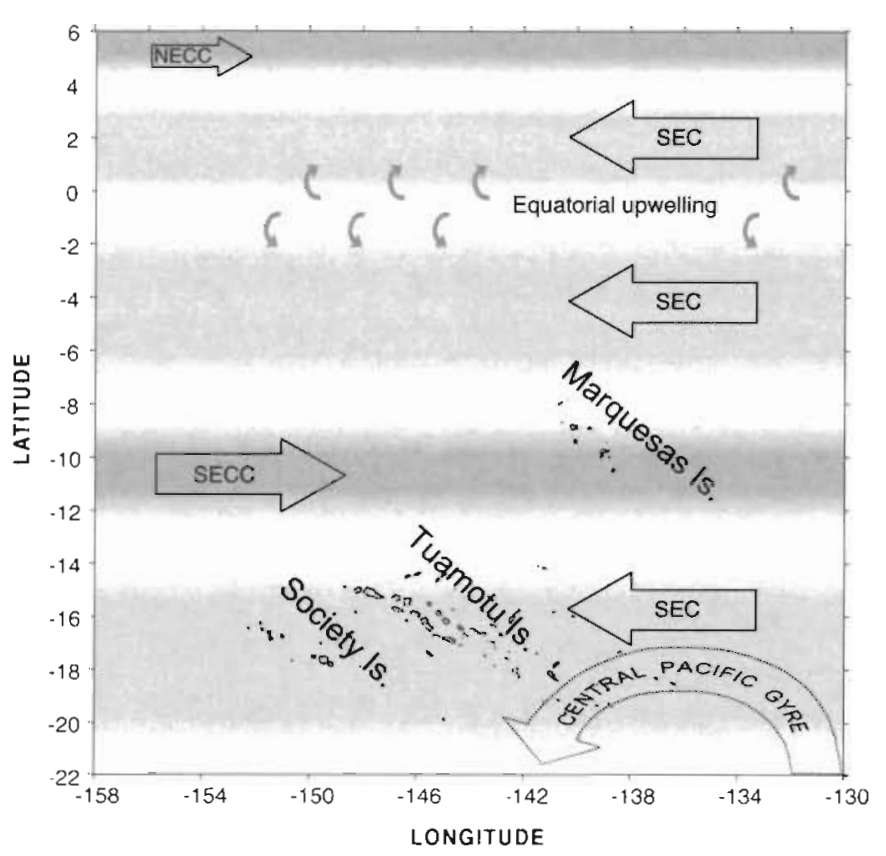

Fig. 9. Schematic current features in the Polynesian EEZ area

$12^{\circ} \mathrm{S}$, a result which agrees with the particle load maximum at the southern convergence zone.

However, micronekton could be located not in the convergence area but closer to the mesozooplankton maximum so that other factors controlling micronekton distribution, such as the distribution of dissolved oxygen concentrations, need to be found. Thus, mineralisation of organic matter uses oxygen, and active mineralisation areas are therefore oxygen deficient. In the equatorial area, mineralisation of organic matter starts at the base of the photic layer, in the pycnocline. As a result, ammonium and nitrite maximums are observed in the pycnocline, the depth of which increases from the equator to the southern convergence zone (Fig. 4 of Murray et al. 1995). Nutrient profiles of Murray et al. (1995) at $140^{\circ} \mathrm{W}$ can be used as reference since temperature, salinity and dissolved oxygen distribution were very similar during the ECOTAP programme (Fig. 11) and the Eqpac Survey II. The value of the density gradient is important when considering exchanges between the mixed layer and the deeper layers, particularly as far as oxygen concentrations are concerned. Between 0 and $6^{\circ} \mathrm{S}$, a strong pycnocline around 100 to $150 \mathrm{~m}$ leads to particularly low $\mathrm{O}_{2}$ values below $100 \mathrm{~m}$ $\left(<1.5 \mathrm{ml} \mathrm{l}^{-1}\right)$. However, south of $6^{\circ} \mathrm{S}$, density gradients become lower and $\mathrm{O}_{2}$ concentrations start to increase underneath the pycnocline. As a result, oxygen concentration exceeds $3.4 \mathrm{ml} \mathrm{l}^{-1}$ at the nitrite maximum depth between 8 and $12^{\circ} \mathrm{S}$. A similar pattern has already been described in the Western Pacific $\left(170^{\circ} \mathrm{E}\right)$ south equatorial convergence zone by Oudot (1978).
To suppose that micronekton avoids the very low oxygen depths prevailing below the mixed layer between 0 and $6^{\circ} \mathrm{S}$ seems to be a realistic hypothesis considering bibliographical data and present observations. Thus, as shown in Fig. $4 \mathrm{~b}$, very low acoustic detections are observed during the day, underneath the $1.5 \mathrm{ml} \mathrm{l}^{-1}$ oxygen isoline when all ECOTAP data are considered. Similarly, Sameoto (1986), Andersen et al. (1997) and Le Borgne \& Rodier (1997), report on the effect of low $\mathrm{O}_{2}$ concentrations on the vertical distribution of mesozooplankton and micronekton. To conclude, micronekton would find both significant particulate biomasses and reasonable oxygen concentrations in the deep levels at the convergence zone.

Finally, the structure of the foodweb may partly explain micronekton biomass levels and vertical distribution in the ECOTAP area. In the equatorial upwelling, occurrence of macronutrients (such as nitrate or orthophosphate) in the photic layer allows production of more large phytoplanktonic cells than in oligotrophic areas which are nutrient-limited (Le Bouteiller et al. 1992). As a result, mesozooplankton diet consists of a greater proportion of phytoplankton in the former case, leading to a closer relationship between phytoplankton and mesozooplankton. According to Le Borgne \& Rodier (1997), the consequence is a surface-oriented distribution and small diel migrations of the mesozooplankton of the equatorial Pacific. The inverse situation is observed in the oligotrophic areas with a more homogeneous vertical distribution and significant diel migrations. This may be the case for micronekton, which feeds on the mesozooplankton, and does not contradict the 'oxygen concentration' explanation. In the northern part of the ECOTAP area, which is situated in the equatorial upwelling, micronekton may be associated with mesozooplankton and

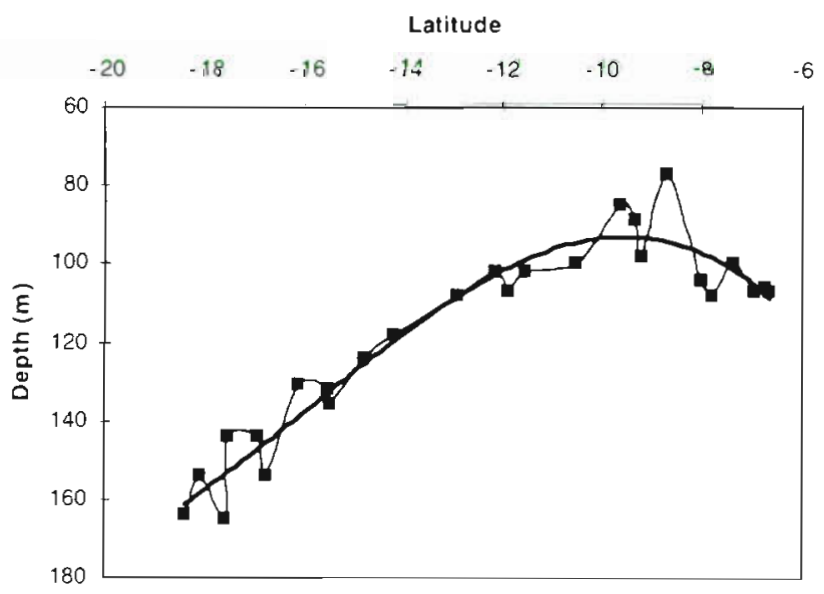

Fig. 10. Latitudinal evolution of the euphotic layer depth determined by the depth of $1 \%$ of incident light (ECOTAP unpubl. data) 

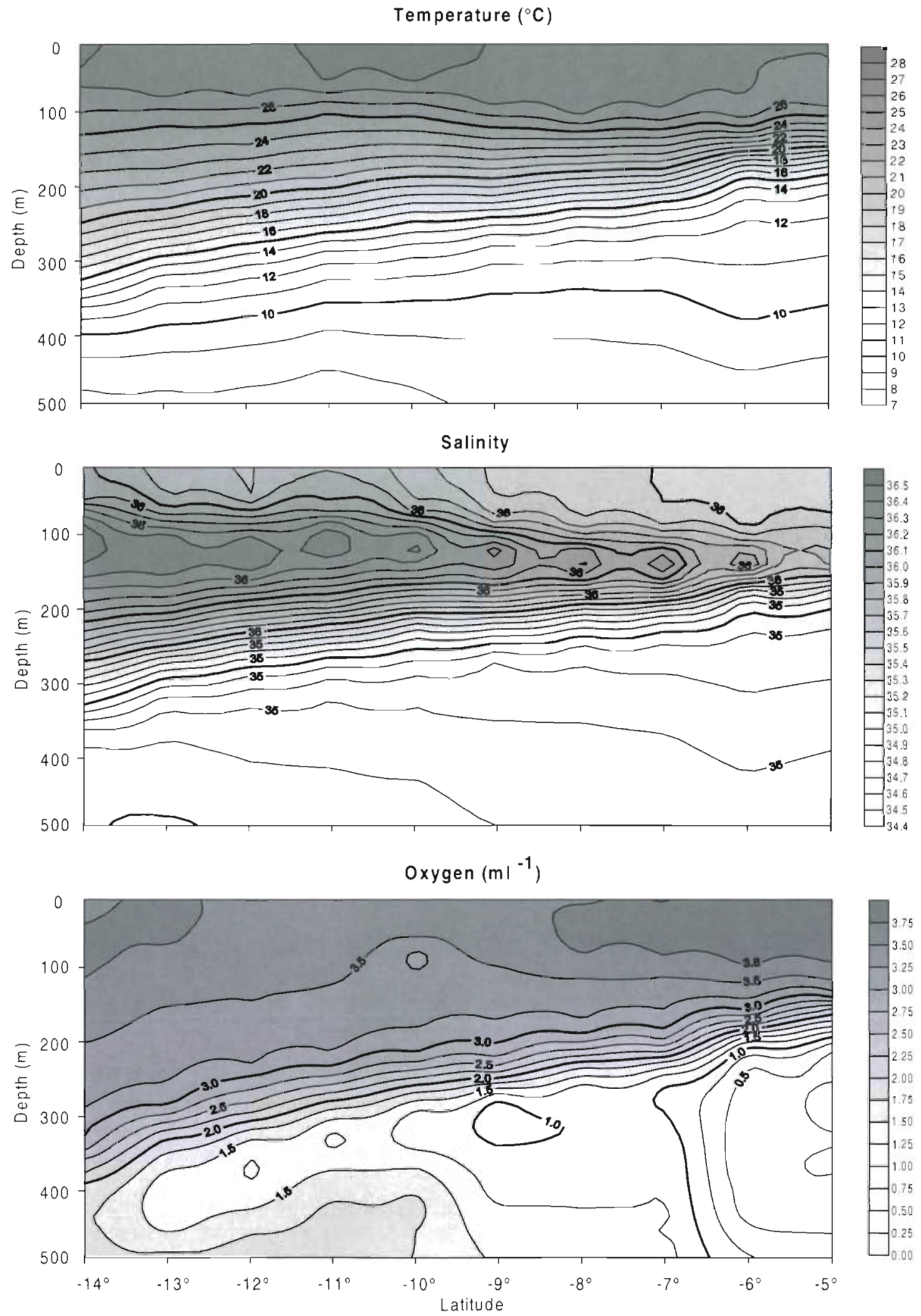

Fig. 11 Temperature, salinity and dissolved oxygen from 5 to $14^{\circ} \mathrm{S}$ at $140^{\circ} \mathrm{W}$ during the ECOTAP programme (ECOTAP unpubl. data) 


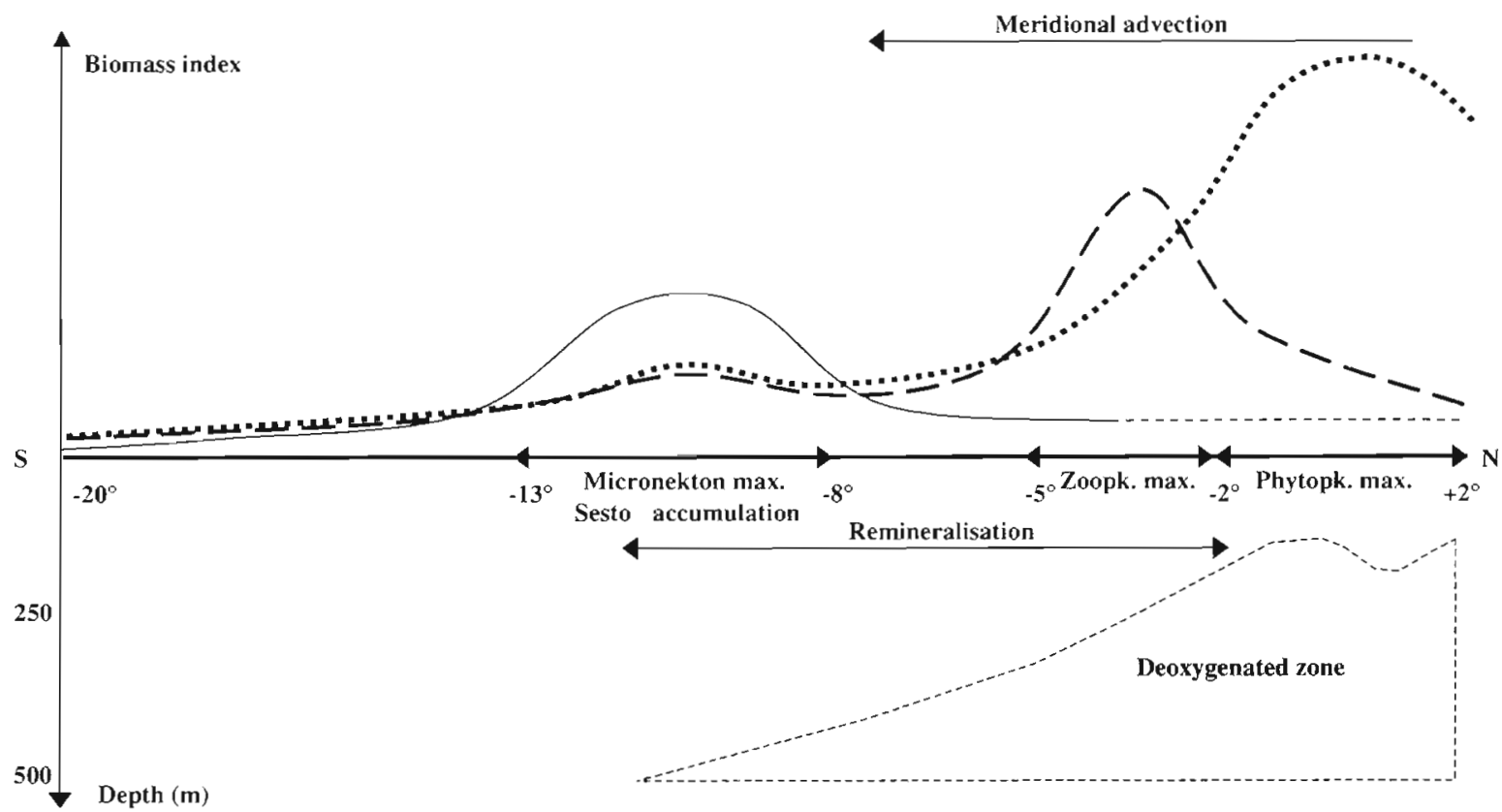

Fig. 12. Schematic representation of latitudinal distribution of phytoplankton (dotted line), zooplankton (dashed line) and micronekton (solid line) biomass in the $140^{\circ} \mathrm{W}$ zone with respect to latitudinal distribution of the deep deoxygenated zone during a positive Southern Oscillation Index (SOI) period

may display a surface-oriented distribution and small vertical migrations. Its habitat volume would therefore be less significant than further south.

To sum up, interpretation of larger micronekton biomasses south of the Marquesas instead of the northern and equatorial upwelling zone relies on knowledge of the functioning of the equatorial Pacific ecosystem and of the ecology of the micronekton itself. A schematic diagram which synthesises present results and classic knowledge on phytoplankton and zooplankton distribution can be proposed (Fig, 12) and commented as follows: increased primary productivity, which is generated by the divergence of the SEC at the equator, produces zooplankton biomass, the maximum of which is shifted further to the south $\left(2\right.$ to $\left.5^{\circ} \mathrm{S}\right)$ due to the meridian component of the SEC and the generation time of the animals. Micronekton would originate from 2 distinct zones: (1) in the maximum mesozooplankton area, micronekton larvae could take advantage of phytoplankton biomasses in the photic layer and drift southwards as they grow, until, after a month long trip, they find favourable conditions for metamorphosis and downward migration in the convergence zone (around 8 to $12^{\circ} \mathrm{S}$ ), (2) in the convergence zone itself, both larvae and adults could find the appropriate food such as phytoplankton, zooplankton and particles of the microbial foodweb which accumulate in the convergence. South of the south equatorial convergence, micronekton are no longer limited by oxygen in the deep layers, but by food. Thus, the 2 hydrological structures, at 4 to $8^{\circ} \mathrm{S}$ and 13 to $20^{\circ} \mathrm{S}$, would generate similar biomasses and aggregative distributions for different reasons.

\section{CONCLUSION}

Acoustic data collected extensively in the French Polynesian EEZ over 2 yr, between 4 and $20^{\circ} \mathrm{S}$ and 134 and $154^{\circ} \mathrm{W}$, were used in the study of micronekton biomass distribution. They led to the definition of 3 different areas. The richest zone is located between Marquesas and a NW-SE oriented 11 to $14^{\circ} \mathrm{S}$ line, and is not as close to the equator as would be expected from published results on primary and secondary production latitudinal distribution. This result may be ascribed to the location of the south equatorial convergence, which concentrates particles and presents no oxygen limitation in the deep layers. North and south of the richest zone, different hydrological features, but a comparable abundance of micronekton, are encountered. To the north, waters are enriched by the equatorial upwelling, but intense organic matter remineralisation limits oxygen availability under the mixed layer. To the south, waters are influenced by the great southern gyre and display oligotrophic features, which are less favourable to micronekton development.

From the present study, it appears that micronekton distribution and biomass rely on both trophic and environmental factors. Therefore, predictive models of 
tuna forage, which are usually based on direct relationships between micronekton and lower trophic levels, are not always appropriate. Such models should also take environmental limiting factors, such as dissolved oxygen, into account. Moreover, acoustic studies provide a multidimensional description of micronekton habitat, and should be used in order to validate any modelled tuna forage description.

Acknowledgements. This research was supported by the Government of French Polynesia. The authors wish to thank the officers and crew of the RV 'A.LIS' for their kind assistance during experiments. Sincere thanks are extended to all of our colleagues from SRM (ex-EVAAM), IFREMER and IRD (exORSTOM), who worked with us during the ECOTAP programme. The authors are also grateful to $C$. Oudot for his helpful discussions. The authors are grateful for the helpful insights and comments of the 3 referees.

\section{LITERATURE CITED}

Andersen V, Sardou J, Gasser B (1997) Macroplankton and micronekton in the Northeast tropical Atlantic: abundance, community composition and vertical distribution in relation to different trophic environments. Deep-Sea Res I $44: 193-222$

Barber RT, Sanderson MP, Lindley ST, Chai F, Newton J, Trees CC, Foley D (1996) Primary productivity and its regulation in the equatorial Pacific during and following the 1991-1992 El Niño. Deep-Sea Res II 43:933-969

Blackburn M (1968) Micronekton of the eastern tropical Pacific Ocean: family composition, distribution, abundance, and relations to tuna. Fish Bull US 67:71-115

Chavez FP, Buck KR, Service SK, Newton J, Barber RT (1996) Phytoplankton variability in the central and eastern tropical Pacific. Deep-Sea Res II 43:835-870

Coyle OC, Weingartner TJ, Hunt GL Jr (1998) Distribution of acoustically determined biomass and major zooplankton taxa in the upper mixed layer relative to water masses in the western Aleutian lslands. Mar Ecol Prog Ser 165: $95-108$

Cushing DH (1959) The seasonal variation in oceanic production as a problem in population dynamics. J Cons Int Explor Mer 24:455-464

Fiedler CP, Barlow J, Gerrodette T (1998) Dolphin prey abundance determined from acoustic backscatter data in eastern Pacific surveys. Fish Bull 96:237-247

Fonteneau A (1997) Atlas of tropical tuna fisheries. World catches and environment. ORSTOM, Paris

Foote (1980) Importance of the swimbladder in acoustic scattering by fish: a comparison of gadoid and mackerel target strength. J Acoust Soc Am 67:2084-2089

Grandperrin R (1975) Structures trophiques aboutissant aux thons de longue ligne dans le Pacifique sud-ouest tropical. Thèse de l'Université d'Aix-Marseille II, ORSTOM, Paris

Guillard J, Gerdeaux D, Chautru JM (1990) The use of geostatistics for abundance estimation by echo-integration in lakes: the example of Lake Annecy. Rapp P-V Reun Cons Int Explor Mer 189:410-414

Jefferts K, Burczynski J, Pearcy WG (1987) Acoustical assessment of squid (Loligo opalescens) off the Central Oregon coast. Can J Fish Aquat Sci 44:1261-1267

Josse E, Bach P, Dagorn L (1998) Simultaneous observations of tuna movements and their prey by sonic tracking and acoustic surveys. Hydrobiologia 37 1/372:61-69

Kajiwara Y, Iida K, Kamei Y (1990) Measurement of target strength for the flying squid (Ommastrephes bartrami). Bull Fac Fish Hokkaido Univ 41:205-212

Kimura $S$, Kasai A, Nakata $H$, Sugimoto $T$, Simpson $\mathrm{JH}_{\text {, }}$ Cheok JVS (1997) Biological productivity of meso-scale eddies caused by frontal disturbances in the Kuroshio. ICES J Mar Sci 54:179-192

Kitchell JF, Neill WH, Dizon AE, Magnuson JJ (1978) Bioenergetic spectra of skipjack and yellowfin tunas. The physical ecology of tunas. In: Sharp GD, Dizon AE (eds) The physiological ecology of tunas. Academic Press, New York, p 357-368

Kloser RJ, Williams A, Koslow JA (1997) Problems with acoustic target strength measurements of a deepwater fish, orange roughy (Hoplostethus atlanticus, Collett). ICES J Mar Res 54:60-71

Koslow JA, Kloser RJ, Williams A (1997) Pelagic biomass and community structure over the mid-continental slope off Southeastern Australia based upon acoustic and midwater trawl sampling. Mar Ecol Prog Ser 146:21-35

Landry MR (1981) Switching between herbivory and carnivory by the planktonic marine copepod Calanus pacificus. Mar Biol 65:77-82

Le Borgne R, Rodier M (1997) Net zooplankton and the biological pump: a comparison between the oligotrophic and mesotrophic equatorial Pacific. Deep-Sea Res II 44:2003-2023

Le Borgne R, Herbland A, Le Bouteiller A, Roger C (1983) Zooplankton and micronekton biomass in the open-ocean of the Gulf of Guinea: relations with phytoplankton and particulate matter. Oceanogr Trop 18:419-460

Le Bouteiller A, Blanchot J, Rodier M (1992) Size distribution patterns of phytoplankton in the Western Pacific: towards a generalisation for the tropical open ocean. Deep-Sea Res 39:805-823

Legand M, Bourret P, Fourmanoir P, Grandperrin R, Gueredrat JA, Michel A, Rancurel $P$, Repelin $R$, Roger $C$ (1972) Relations trophiques et distributions verticales en milieu pélagique dans l'Océan Pacifique intertropical. Cah ORSTOM Sér Océanogr 10:303-393

Lehodey P, Bertignac M, Hampton J, Lewis A, Picaut J (1997) El Niño southern oscillation and tuna in the western Pacific. Nature 389:715-718

Lehodey $P$, Andre JM, Bertignac M, Hampton J, Stoens A, Menkes C, Memery L, Grima N (1998) Predicting skipjack tuna forage distributions in the equatorial Pacific using a coupled dynamical bio-geochemical model. Fish Oceanogr $7: 317-325$

Levin SA (1992) The problem of pattern and scale in ecology. Ecology 73:1943-1967

Lindley ST, Bidigare RR, Barber RT (1995) Phytoplankton photosynthesis parameters along $140^{\circ} \mathrm{W}$ in the equatorial Pacific. Deep-Sea Res II 42:441-463

Longhurst A. (1998) Ecological geography of the sea. Academic Press, London

MacLennan DN, Simmonds EJ (1992) Fisheries acoustics. Chapman and Hall, London

Marchal E, Lebourges A (1996) Acoustic evidence for unusual diel behaviour of a mesopelagic fish (Vincinguerria nimbaria) exploited by tuna. ICES J Mar Sci 53:443-447

Marchal E, Gerlotto F, Stequert B (1993) On the relationship between scattering layer, thermal structure and tuna abundance in the Eastern Atlantic Equatorial current system. Oceanol Acta 16:261-272

Matheron G (1965) La théorie des variables régionalisées et ses applications. Masson et Cie, Paris 
Mitson RB, Simard Y, Goss C (1996) Use of a two-frequency algorithm to determine size and abundance of plankton in three widely spaced locations. ICES J Mar Sci 53:209-215

Murray JW, Johnson E, Garside CA (1995) JGOFS process study in the equatorial Pacific (EqPac): introduction. Deep-Sea Res II 42:275-293

Olson RJ, Boggs CH (1986) Apex predation by yellowfin tuna (Thunnus albacares): independent estimates from gastric evacuation and stomach contents, bioenergetics, and cesium concentrations. Can J Fish Aquat Sci 43:1759-1775

Oudot C (1978) Continuité zonale et circulation méridienne du maximum de nitrite dans le Pacifique equatorial sudouest. II. Interprétation: aspect de la régénération des sels nutritifs. Cah ORSTOM Sér Océanogr 16:363-376

Pelletier D, Parma AM (1994) Spatial distribution of Pacific Halibut (Hippoglossus stenolepis): an application of geostatistics to longline survey data. Can J Fish Aquat Sci 51:1506-1518

Petitgas P (1993) Geostatistics for fish stock assessments: a review and an acoustic application. ICES I Mar Sci 50: $285-298$

Petitgas P, Levenez JJ (1996) Spatial organisation of pelagic fish: echogram structure, spatio-temporal condition, and biomass in Senegalese waters. ICES J Mar Sci 53:147-153

Petitgas P. Prampart A (1995) EVA: a geostatistical software for structure analysis and variance computation. ORSTOM, Paris

Piontkovski SA, Williams R (1995) Multiscale variability of tropical ocean zooplankton biomass. ICES J Mar Sci 52: $643-656$

Power JH (1996) Simlations of the effect of advective-diffusive processes on observations of plankton abundance and population rates. J Plankton Res 18:1881-1896

Pujo-Pay M (1995) L'azote et le phosphore en milieu marin. L'importance des formes organiques en milieu océanique du large. Thèse de l'Université de la Méditerranéem, Marseille

Roger C (1994) The plankton of the tropical Western Indian ocean as a biomass indirectly supporting surface tunas (yellowfin, Thunnus albacares and skipjack, Katsuwonus pelamis). Environ Biol Fish 39:161-172

Roger C. Marchal E (1994) Mise en évidence de conditions favorisant l'abondance des Albacores (Thunnus alba. cares) et des Listaos (Katsuwonus pelamis) dans l'Atlantique Equatorial Est. IATIC Rec Doc Sci 32:237-248

Rougerie F, Rancher J (1994) The Polynesian South Ocean: features and circulation. Mar Pollut Bull 29:14-25

Sameoto DD (1986) Influence of the biological and physical environment on the vertical distribution of mesozooplankton and mirronekton in the eastern tropical Pacific. Mar Biol 93:263-279

Editorial responsibility: Otto Kinne (Editor), Oldendorf/Luhe, Germany
Saporta G (1990) Probabilités, analyse de données et statistiques. Technip, Paris

Simard Y, Marcotte D, Bourgault G (1993) Exploration of geostatistical methods for mapping and estimating acoustic biomass of pelagic fish in the gulf of St. Lawrence: size of echo-integration unit and auxiliary environmental variables. Aquat Living Resour 6:185-199

Simrad (1993) Simrad EK500 Scientific echo sounder operator manual. Simrad Subsea A/S Horten, Norway

Sullivan PJ (1991) Abundance estimation using depth-dependent trends and spatially correlated variation. Can J Fish Aquat Sci 48:1691-1703

Sund PN, Blackburn M, Williams F (1981) Tunas and their environment in the Pacific Ocean: a review. Oceanogr Mar Biol Annu Rev 19:443-512

Swartzman G, Huang C, Kaluzny S (1992) Spatial analysis of Bering Sea groundfish survey data using generalised additives models. Can J Fish Aquat Sci 49:1366-1378

Vinogradov ME (1981.) Ecosystems of equatorial upwellings. In: Longhurst AR (ed) Analysis of marine ecosystems. Academic Press, London, p 69-93

Vinogradov ME, Shushkina EA, Vedernikov VI, Nelzin NP, Gagarin VI (1997) Primary production and plankton stocks in the Pacific Ocean and their seasonal variation according to remote sensing and field observations. Deep-Sea Res II 44:1979-2001

Walsh JJ (1976) Herbivory as a factor in patterns of nutrient utilization in the sea. Limnol Oceanogr 21:1-13

White JR, Zhang X, Welling LA, Roman MR, Dam HG (1995) Latitudinal gradients in zooplankton biomass in the tropical Pacific at $140^{\circ} \mathrm{W}$ during the JGOFS EqPac study: effects of El Niño. Deep-Sea Res II 42:715-733

Wiebe PH (1970) Small-scale spatial distribution in oceanic zooplankton. Limnol Oceanogr 15:205-217

Wyrtki K, Kilonsky B (1984) Mean water and current structure during the Hawaii-to-Tahiti shuttle experiment. J Phys Oceanogr 14:242-254

Yamamoto T, Nishizawa S (1986) Small-scale zooplankton aggregation at the front of a Kuroshio warm-core ring. Deep-Sea Res 33:1729-1740

Young JW, Bradfort RW, Lamb TD, Lyne VD (1996a) Biomass of zooplankton and micronekton in the southern bluefin tuna fishing grounds off eastern Tasmania, Australia. Mar Ecol Prog Ser 138:1-14

Young JW, Lamb TD, Bradfort RW (1996b) Distribution and community structure of midwater fishes in relation to the subtropical convergence off eastern Tasmania, Australia. Mar Biol 126:571-584

Zhou M, Huntley ME (1996) The principle of biological attraction, demonstrated by the bio-continuum theory of zooplankton patch dynamics. J Mar Res 54:1017-1037

Submitted: February 3, 1999; Accepted: August 2, 1999

Proofs received from author(s): December 12, 1999 